УАК 37.091.12: [94+34]: 005.963

DOI 10:25128/2415-3605.18.1.8

LILIIA RIABOVOL

ORCID iD 0000-0003-3558-2103

1ryabovo18@gmail.com

doctor of pedagogical sciences, associate professor associate professor of the department of state law disciplines and administrative law Volodymyr Vynnychenko Central Ukrainian State Pedagogical University

(Kropyvnytskyi, Ukraine)

\title{
THE SYSTEM OF PEDAGOGICAL EDUCATION AND TRAINING OF A HISTORY AND LAW TEACHER: MODERNIZATION IN THE CONTEXT OF INTEGRATION INTO THE EUROPEAN AND WORLD EDUCATIONAL SPACE
}

Pedagogical education and professional training of history and law teachers is a complex multicomponent formation, a system aimed at ensuring the conditions for obtaining and improving of the educational and professional level of the teachers of the respective subjects. In the article it has been viewed in its wide sense as a macro system, the system-forming component of which is the aggregate of the normative legal acts as the basis for its functioning. The network of higher educational institutions providing teachers training has been defined as a component of the system under study. The results of the analysis of the approaches to the organization of pedagogical education and teachers training in different countries have been outlined. General secondary education institutions as the bases of practical training of future teachers have been indicated as the element of this system. Pedagogical education and professional training have to be carried out continuously; therefore, the corresponding network includes the institutions of in-service training. In general terms, the roles of the Ministry of Education and Science of Ukraine as a body carrying out the management in the sphere of education. The component of the system under study is the participants of the educational process. In their narrow meaning pedagogical education and professional training of the teachers of history and law are described as a training system which operates through the implementation of the relationships between the target, substantial, organizational and effective its components. The potential abilities to updating of those components in the context of the European integration, in particular, the goal setting, designing of the content, selecting of the technologies, determining of the results based on the competence approach have been reviewed. The professional competence of a teacher of history and law, the innovative methods and technologies of training and the like has been recognized as the prospective areas of the research.

Keywords: system, pedagogical education, professional training, teacher of history and law, competencebased approach, European educational space, integration, European educational values.

АІАІЯ РЯБОВОА

доктор педагогічних наук, доцент Центральноукраїнський державний педагогічний університет імені Володимира Винниченка вул. Шевченка 1, м. Кропивницький

\section{ПРОФЕСІЙНА ПІАГОТОВКА ВЧИТЕАЯ ІСТОРІЇ ТА ПРАВОЗНАВСТВА В СИСТЕМІ ПЕААГОГІЧНОЇ ОСВІТИ: МОАЕРНІЗАЦІЯ У КОНТЕКСТІ ІНТЕГРАЦІЇ УКРАЇНИ У СВІТОВИЙ ТА ЄВРОПЕЙСЬКИЙ ОСВІТНІЙ ПРОСТІР}

Показано, щзо педагогічна освіта та професійна підготовка вчителя історії $і$ правознавства складне багатокомпонентне утворення, система, спрямована на забезпечення умов для набуття $i$ підвищення освітньо-професійного рівня вчителя відповідних предметів. У иирокому розумінні ї̈ розглянуто, як макросистему, системотвірним компонентом визначено сукупність нормативноправових актів, що закладають законодавче підтрунтя ї̈ функціонування, та нормативних документів, на основі яких здійснюється підготовка таких фахівців з вищою освітою. В загальних рисах описано роль Міністерства освіти і науки Украӥни як державного органу, що здійснює управління у сфері освіти, а також наукових установ, які беруть участь в розробиі теоретико-методологічних підвалин змісту вищої та загальної середньої освіти. Встановлено, щчо складником досліджуваної системи є мережа 
вищих навчальних закладів, які забезпечують підготовку педагогічних кадрів. Враховуючи, що педагогічна освіта та професійна підготовка вчителів мають здійснюватися неперервно, в ињю мережу включено заклади післядипломної педагогічної освіти. Визначено роль такого елементу вказаної системи, як загальноосвітні навчальні заклади, що є базами педагогічних практик майбутніх вчителів. Як компонент досліджуваної системи описано учасників відповідного освітнього процесу. У вузькому розмінні педагогічну освіту та професійну підготовку вчителя історії та правознавства розглянуто як систему навчання, що функціонує завдяки реалізації взаємозв'язків між цільовим, змістовим, організаційним та результативним компонентами. Окреслено потениійні можливості оновлення цих компонентів у контексті євроінтеграції, зокрема, щүодо цілевизначення, конструювання змісту, відбору технологій, визначення результатів навчання на засадах компетентнісного підходу. Викладено результати аналізу підходів до організачії педагогічної освіти і професійної підготовки вчителів у різних краӥнах. У контексті інтеграиії вітчизняної освіти в європейський освітній простір акиентовано на необхідості модернізації системи педагогічної освіти та професійної підготовки вчителя історії $i$ правознавства.

Ключові слова: система, педагогічна освіта, професійна підготовка, вчитель історії та правознавства, компетентнісний підхід, європейський освітній простір, інтеграція, європейські педагогічні иінності.

\section{АИАИЯ РЯБОВОА}

доктор педагогических наук, доцент Центральноукраинский государственный педагогический університет имени Владимира Винниченко

ул. Шевченко 1, г. Кропивницкий

\section{И ПРОФЕССИОНААЬНОЙ ПОАГОТОВКИ УЧИТЕАЯ ИСТОРИИ И ПРАВОВЕАЕНИЯ В СИСТЕМЕ ПЕААГОГИЧЕСКОГО ОБРАЗОВАНИЯ: МОАЕРНИЗАЦИЯ В КОНТЕКСТЕ ИНТЕГРАЦИИ УКРАИНЫ В МИРОВОЕ И ЕВРОПЕЙСКОЕ ОБРАЗОВАТЕАЬНОЕ ПРОСТРАНСТВО}

Отмечено, что педагогическое образование и профессиональная подготовка учителя истории и правоведения - сложная многокомпонентная система, направленная на создание условий для получения u повышения образовательно-профессионального уровня учителя данных предметов. Эту систему рассмотрено в иироком понимании, как макросистему, которая охватывает такие компоненты: нормативно-правовые акты как основа ее функиионирования (системообразующий компонент); сеть высших учебных заведений, в которых осуществляется подготовка педагогических кадров; общеобразовательные учебные заведения как база педагогических практик будущих учителей; заведения последипломного образования, которые призваны обеспечивать непрерывность педагогического образования и соответствующей профессиональной подготовки; Министерство образования и науки Украини как государственный орган, осуществляющий управление в сфере образования; научные учреждения, которые принимают участие в разработке теоретико-методологической базы содержания высшего и среднего общего образования; участники образовательного процесса. В узком понимании педагогическое образование и профессиональную подготовку учителя истории и правоведения описано как систему обучения, которая функиионирует благодаря реализации взаимосвязей между целевым, содержательныл, организационным и результативным ее компонентами. Изложено результаты анализа подходов $\kappa$ организации педагогического образования и профессиональной подготовки учителей в разных странах. Акцентировано на необходимости модернизации отечественной системы педагогического образования и профессиональной подготовки учителей в контексте евроинтеграции. Определен потенцииал обновлення ее компонентов на компетентностных основах.

Ключевые слова: система, педагогическое образование, профессиональная подготовка, учитель истории и правоведения, компетентностный подход, европейское образовательное пространство, интеграџия, европейские педагогические ценности.

The system-based approach has been widely implemented in the scientific and educational research. To refer to the complex pedagogical phenomena and highlight their entity such categories as the system of education, the educational system, the pedagogical system, the didactic system, the system of pedagogical education, and the like are used. The introduction of the term «pedagogical education and professional training of a history and law teacher» is based on the provisions of the 
current legislation. According to the Law of Ukraine «On general secondary education», a pedagogical employee is a person with high moral traits who has the pedagogical education, the appropriate level of the professional training (art. 24) [7, p. 1].

The problem of the training of the teachers of social science subjects causes a significant scientific interest of the native and foreign experts. Various aspects of their professional training in Ukraine and other countries were researched by T. Andrews, R. Bain, T. Bakka, K. Bakhanov, F. Burke, D. A. Cantù, G. Kashkariov, A. Nikora, B. Pasichnyk, N. Quam-Wickham, V. Snagoshchenko, A. Stareva etc. However, pedagogical education and training of a history and law teacher was not the subject of a comprehensive research and was not studied as a complex multifaceted phenomenon requiring systematic analysis. That caused the topic and purpose of our article.

The objective of this article is to explore pedagogical education and training of a history and law teacher as a complex formation and to determine the directions of its modernization in the context of the integration into the European and world educational space.

The scientific researches in the field of education that implement a systematic approach, are based on the provisions of the law in which there are two approaches to the description of education as a system. For the first it is a network of the educational establishments and other institutions in the field of education. This approach narrows the vision of the system of education and does not fully reflect its amount and content. Another approach is realized, for example, in the Law «On education». The system of education is an entity of the subjects of educational activities; the participants of the educational process; the educational programs; the levels and degrees (qualifications) of education; the standards of education; the licensing conditions; the bodies exercising administration in the field of education (art. 1) [8, p. 21]. As we can see, the interpretation of the system of education has been greatly expanded, it is not limited to the network of the educational institutions, and on the contrary, it covers various categories of the participants and normative documents of the organization of the educational process and carrying out of the educational activities. In our study the system of pedagogical education and professional training of history and law teachers is considered from the standpoint of the second approach.

Pedagogical education and professional training of history and law teachers is a functionally differentiated educational system which is focused on providing conditions for obtaining and improving of the educational and professional level of the teachers of the respective subjects. It is a socially determined system because it operates in the society and is designed to perform a specific social order, to meet a pressing social need of training of the teachers with the necessary professional qualities.

The backbone component of the system, the basics of its functioning is a set of the legal acts. The basic among these is the Constitution of Ukraine. Article 53 of this document stipulates that everyone has the right to education including higher and postgraduate one, and the state provides its availability and development. The constitutional provisions find their development in the Laws «On education» [8], «On higher education» [6] and others. Thus, the Law «On higher education», adopted in line with the integration of the national education into the European educational space, provided higher education institutions to make decisions regarding the organization of the educational process independently, in particular, to implement the innovative forms, methods, technologies of training of future teachers. It proclaims the lifelong education principle and focuses the learning on the result.

The rightful place in the legislation on pedagogical education is occupied by the Branch Concept of the development of the continuous pedagogical education (further - the Branch Concept) which defines the principles, objectives, conditions for the development of such education, its system, contents and organization [4]. The Pedagogical Constitution of Europe is significant for the further development of the national pedagogical education in the context of the European integration. Its adoption is due to the unification of the educational processes that take place in modern Europe and encourage the search for the common principles of the complex architecture of the professional training of teachers. The document outlines the main parameters of the pedagogical education: principles of its development, content, conditions, results [13].

An integral part of the system of pedagogical education and professional training of history and law teachers are the normative documents that underpin the training of the relevant specialists with higher education on the levels of a «bachelor» and a «master» (educational and professional program) in the direction of the training «Secondary education (History)», the specialization «Law». Such documents are the standards of the educational activities; the standards of higher education; the 
educational (educational and professional) program; the curriculum; the educational and operating program in the disciplines, which are studied according to the curriculum.

The network of the higher educational institutions, providing teachers training, is made up by the pedagogical colleges which can function as independent educational institutions, and as structural units of the pedagogical or classical universities, pedagogical academies, universities, classical universities, and other institutions of higher education provided that they fulfil the requirements for the higher education standards of the pedagogical specialities [4]. It should be noted that the question «What educational institutions should provide teachers training: either classical, or pedagogical universities?» has not lost its relevance and is solved differently in different countries. For example, in Poland history teachers training is carried out in 13 universities and 12 teachers training institutes. In order to obtain the qualification of a «teacher of History and Social Sciences», the students of both types of the educational institutions have to learn the required course of the psychological and pedagogical disciplines in the total amount of 270 hours and participate in school practice (150 hours) $[12$, p. 9]. In Ontario, teacher training has passed a long way from the teaching college to the teaching faculty at University. Today, in order to obtain a certificate for the conduct of teaching activities one should obtain a bachelor's degree and go through a two-year training programme for the teachers. While the pedagogical education is available at University, the accreditation and certification (secondary) are conducted by the Ontario College of Teachers [9, p. 56]. The alternative access paths to the teaching profession have been developed in the world practice [2, pp. 19, 24].

Having based on the fact that the pedagogical education is a specific educational system, it requires a special organization that is reflected in the goals, content, learning technologies of a teacher. The educational process in the pedagogical universities should include a research component; however, it should not dominate here in contrast to the classical universities. So, the pedagogical education should be acquired in its respective professional schools. According to the national practice, the overwhelming majority of the teachers of history and law acquire the pedagogical education and professional training in pedagogical universities. In their structure there is the Department of History and its chairs that conduct the educational, methodological, and scientific activity in the speciality of «History» and the specialization of «Law». The scientific and research (educational and scientific) laboratory of social science studies can work in the structure of the faculty. General secondary education institutions, as the bases of the practical training of future teachers, should be referred to the subjects of the educational activity in the field of the pedagogical education.

The changes in the vision of the ideal of the educated person, due to cultural and spiritual, socio-economic, technological transformations, challenges of the global, European, national, regional and local levels require constant improvement of the teacher training [4]. This means that pedagogical education must become the lifelong education, and professional training must be continuous.

The specialized improvement of education and professional training of individuals is carried out by the deepening, expanding and updating of its knowledge and skills on the basis of the previously obtained higher education (speciality) and practical experience in the process of in-service training, the main ways of which are: retraining, qualification improvement, internships, participation in the certification programs, training courses, workshops not only in Ukraine but also abroad (art. 59, art. 60 the Law «On education») [8, p. 3].

Having based on the fact that pedagogical education and professional training of the teachers of history and law involves not only a particular level of the higher education under the relevant speciality and specialization, but also a systematic training, it is not limited to the higher educational institutions but includes the institutions of in-service training (pedagogical academies, universities, institutes). The purposes of these activities are increasing of the professional competence of the teachers of secondary schools in the system of the continuous pedagogical education; providing of the scientific and organizational and methodical support of the educational process modernization aimed at the improving the quality of teaching in the educational system of the region, and the like.

The implementation of the state-public management and partnership as the principles of the state policy in the sphere of education and the principles of the educational activities, enshrined in the Law «On education», is expanding the list of the subjects of the educational activities at the expense of the public organizations. We can note that they take an active part in the development of the educational systems in different countries. For example, the American Historical Association, its teaching division, is developing the initiatives aimed at improving the teachers training for teaching history in 
different educational establishments and at different levels, and is involved in the creation and scientific substantiation of the content of the professional training of the teachers of history [15, p. 519].

The authorities exercising control in the sphere of education, especially the Ministry of education and science of Ukraine (MESU), are the components of the studied by us system. The divisions of the Department of higher education perform the following main tasks: elaboration of the draft laws and regulatory documents on higher education; optimising of the network of higher educational establishments and institutions of in-service training; formation of the list of the disciplines and specialities according to which the applicants for higher education are trained; organization of the development of the standards for the educational activities and standards for higher education, and the like. The division of the educational content of the Department of general secondary and preschool education organizes the development of the state standards, curricula, program, textbooks.

The system of pedagogical education and professional training of the teachers of history and law includes the academic institutions aimed at the development of pedagogy, history, jurisprudence as a theoretical and methodological basis for selecting and designing the content of higher as well as general secondary education institutions. They are: the National Academy of Sciences of Ukraine, in particular the Institute of History of Ukraine, the National Academy of Pedagogical Sciences of Ukraine (NAPSU), the National Academy of Legal Sciences of Ukraine, etc. A special role among them is played by the Institute of Pedagogy NAPSU, the Department of Social Science Education. Its staff are developing the actual challenges of the school social science education, teaching models, teaching materials; conduct extensive educational work among the supervisors and teachers of the social science subjects such as seminars, trainings, conferences, round-tables, pedagogical readings; collaborate with the experimental secondary educational establishments, higher educational establishments and institutions of in-service training. The activities of these institutions concerning development of the standards for general secondary and higher education etc. are coordinated by the above-mentioned departments of the MESU.

The invariant components, that are essential to the functioning of any educational system, are the participants of the educational process. In the system of pedagogical education and professional training of teachers of history and law they are teachers and applicants of higher education. The students in this process are characterized by certain cognitive abilities, motives and incentives for learning, temper, will. The teacher should be designated by the professional and pedagogical competence, willingness and ability to carry out pedagogical (educational) and research activities, to self-improve. This is important from the point of view that the quality of higher education is largely provided by the high scientific and pedagogical level of the teaching staff.

The main form of the organization of the system of pedagogical education and professional training of the teachers of history and law is the proper training system which operates through the implementation of the relationships between the target, substantial, organizational and effective its components. The target component covers the purpose and tasks of learning which are defined from the standpoint of the student-oriented, competence-based and activity-based approaches, and assumes that the applicant of education must achieve specific social and personal meaningful results. The implementation of the competence-based approach in the native system of education and consolidation of its provisions into national legislation allows describing the goals and results of education using the terms such as competencies and competence, which are necessary for a person as much as they will help it to fulfil itself in different contexts of life and activities.

The meaning of this system is a collection of the systematized knowledge in pedagogy, psychology, history and law, practical skills, the ways of thinking, the models of teaching activities, professional, philosophical and civic qualities, values, competencies acquired in a higher educational establishment with the qualification of a «Teacher of history and law». The content is defined in the standards for higher education developed for the bachelor and master levels within the relevant speciality and specialization. The standard contains the requirements for the appropriate educational program, which, in addition to the required amount of the ECTS credits, must contain the list of the competencies of the graduates, the normative content of training and forms of the assessment of the applicants' education. The contents embodied in the educational program is the basis for the development of the curriculum which defines the list and volume of the subjects in the ECTS credits, the sequence of the subjects study, the forms of the training courses and their amount, the schedule of 
the educational process, the forms of the formative and summative assessment control action (art. 10 Law «On higher education») [6, p. 3].

The major element of the content is the scientifically sound, systematic knowledge in pedagogy, psychology, history and law. The issue concerning its amount, the ratio of the facts and theories is debatable. In the context of the implementation of Tunning project it is discussed in different countries. In the aspect of the professional training of teachers of social disciplines the search for a response occurs predominantly in the field of studying the capacity of the relevant courses with the purpose of realization of the civic education («civic education») for responsible citizenship («responsible citizenship»). In the views of the researchers there is still no unity. Some of them offer to integrate the knowledge about the citizenship in the history courses deeply, in particular in the introductory course of history of the United States, develop and implement the program of the course «American History and Citizenship», and emphasize that learning should be directed not to memorizing of knowledge, but to the development of the historical thinking [15, p. 537]. Others believe that the development of such a way of thinking with the students will allow them to question the basic description of the national history. However, the majority of the experts (T. Andrews, F. Burke ets.) support the idea that those who study history and those who organize this process, that is the teachers, need to develop critical historical thinking [1, p. 123].

The problem of critical thinking development of the applicants for higher education is relevant in the world. The experts explain it by the fact that Higher education courses have a pervasive tendency to emphasize the rote retention of factual information. In addition, to identify factual knowledge is much easier than to assess critical thinking. However, according to the results of the survey conducted by the American Association of managers in 2012, the abilities to think critically were recognized as the most important skills that are associated with the professional career growth of the employee, the demand for whom will only increase. Accordingly, the universities are encouraged to develop critical thinking skills in the learning process of each discipline and to engage students in the active learning by solving real problems, carrying out original, case studies, modelling, and learning in the team [5, p. 44-45].

In the conditions of competence-based learning, knowledge is not a target in itself but the basis for the formation of the behavioural patterns. Graduates have to learn the appropriate use of knowledge to solve problems in the professional and other spheres of their lives. That's why a special role in the structure of the content, that needs to be learnt by a future teacher, is played by the practical, methodical skills. Practical training, as a traditional form of the practical teachers training, is important for their formation but it needs modernisation, provision of continuity and consistency through the implementation of the informational, cultural, educational, training, practice in accordance with the Pedagogical Constitution of Europe [13]. These provisions, however, are not easy to implement, and not only in Ukraine. Thus, a significant reduction in the state funding of practical training (at schools) observed, for example, in Poland which affects adversely the ability of the use of the pedagogical experience of history teachers in the professional training of the students [12, p. 10].

When a person chooses behaviours in the professional activity inclusively, not only knowledge and skills but also values and attitudes are taken into account. The Pedagogical Constitution of Europe includes the main pedagogical values such as: tolerance, democracy, peacefulness, ecological safety, human rights and solidarity, mercy and conscience, responsibility which is recognized in Europe and should be interiorised by every teacher. In the collaboration they form a spiritual platform which is based on the training of new teachers in the European space [13].

The learning content which is to be acquired by the teachers in the higher educational establishments and institutions of in-service training must ensure the appropriate level of competence and readiness to perform professional tasks. That raises no doubts but, however, there is another problem against this background: What does today's professional training of teachers presuppose: training of a subject teacher or a professional in this sphere? The opinion that the subject teacher meets the needs of the industrial society has been established in the professional environment. The role of pedagogy, psychology, methodological is underestimated in the process of training as far as the subject teacher is taught disciplines but not a pedagogical profession. Training of such a teacher of history and law is defined with a rigid ideological support, and due to that the positions of the Pedagogical Constitution of Europe [13], according to which pedagogical values are of de-ideological and de-partied character, are so important. The post-industrial society requires the professionals of the 


\section{ПРОФЕСІЙНА ОСВІТА}

educational activities who are willing and able to organize the educational process so that to ensure the personal development of each student, its ability to adapt to the changing conditions of life. These are the teachers able to involve each student into active cognitive activity, promote its self-expression, encourage to self-improvement. Mastering of the disciplines and ability to teach them is not an only goal of the professional training for such a teacher but the necessary conditions under which he can ensure the personal development of the student that is a priority objective of the educational activities today. A teacher, as it is indicated in the Concept of a new Ukrainian school [10], ceases to be a sole mentor and source of knowledge. He must fulfil the role of a coach, facilitator, tutor, moderator in the individual educational trajectory of the child. Thus the claim that the professional training of a future teacher requires some targeted development of his personality, skill formation that helps to master pedagogical skills is justified. Therefore, the educational goals must be considered in the unity with the developing ones, the achievement of which assumes a certain specificity of the realization of the didactic structures (stimulating and motivating, controlling and regulating, operational and activityoriented, reflexive) [14, p. 144].

The organizational component of the system of training of future teachers of history and law is a combination of the forms of education (full-time courses, correspondence courses (distance learning); the forms of realization of the educational process (lecture, laboratory, practical, individual class, a seminar); consultations; an individual work; a practical training; control actions); technologies, methods, tools. Training of creative teachers, able to meet the demands of the society for their professional training, ready to meet the educational needs of the groups of students and individual students taking into account peculiarities of their cognitive interests and abilities, able to quickly make appropriate and effective decisions in their professional activities, requires fundamental changes in its organization. The Pedagogical Constitution of Europe [13] recognizes the visualization of knowledge, dialogue, cooperation, constructivism, etc. as the key strategies to the success of a teacher. Therefore, the main ones have to become the technologies of the collective (group) learning. The interactive communication creates the opportunities for the development of communicative skills of future teachers. Participation in the discussions allows to use theoretical knowledge and to transform it into the skills, stimulates the development of thinking, and teaches to listen to another and to find the optimal solutions of the problems. To select and process the sources of information, to analyse, organize and present the material are important for the teachers of social sciences. Project technologies, in particular making «a good history paper» contribute to it [16]. The information and communication technologies in the professional training process of teachers are obvious to be used in the information society of the XXI century.

The increase in diversity in the society, a direct consequence of which is the increasing heterogeneity of the student contingent, the information explosion which has led to the overloaded curricula, the emergence of the alternative sources of information that are carriers of the competing values, the application of new information and communicative technologies are the new phenomena which have defined the XXI century and made a challenge to the teachers of history and their professional training. In the framework of the European educational area all this implies the teacher to possess such qualities as a clear civil position, the system of values, especially tolerance, a democratic style of work, high communicative culture, the ability to involve students in the planning and management of the educational process. A future teacher must be prepared for the teaching in the variety of the student's environment taking into account not only individual psychological and age peculiarities of children, but also the ones of the socio-cultural environment, mentality, ethical, religious, political factors [11, p. 137]. As the international experience of the effective school systems shows, the teaching profession should attract the highly qualified personnel because the quality of the education system itself cannot be higher than the quality of the teachers who work in it. The only way to improve the learning outcomes is to improve teaching [2, p. 33].

The productive component is the last but not less important one by value in the training system. It covers the monitoring (inspection, assessment, evaluation) and learning outcomes as a set of knowledge, abilities, skills, other competences acquired in the process of learning according to a certain educational and professional program which can be identified, quantified and measured (art. 1 the Law «On higher education) [6, p. 19]. This component allows setting the level of the goals achievement by the system. To determine the results of the postgraduate education, the certification of teachers is held, which today is 
recognized as a way of ensuring the quality of education. The novelty, that is proposed to be introduced in the national educational legislation, is the certification of the teaching staff.

Thus, pedagogical education and professional training of the teachers of history and law is a functionally differentiated educational system, specially formed for the purposeful influence on the personality of the teacher in the learning process in the higher educational establishments and professional development with the purpose of forming of certain social and professional qualities. This implies assimilation and gradual increase in the necessary and sufficient amount of the systematic scientific knowledge in pedagogy, psychology, history, law, formation of the specific and practical skills, the ways of thinking, psychological and moral qualities, value orientations, professional competence obtained in the field of knowledge of the Humanities by the qualification of a teacher of history and law at the levels (bachelor and master) of higher and in-service training. As a result of the review of pedagogical education and professional training of teachers of history and law as a macro system we have identified the following its components: the normative and legal acts on the basis of which it operates as well as the normative documents for the organization of training; the bodies of the state regulation, the governance of higher legal education; a network of the institutions which provide appropriate educational services; scientific institutions whose activities are aimed at the development of pedagogy, history, law; teachers and students as participants of higher pedagogical education. As a system of learning pedagogical education and professional training of teachers of history and law operates in the relationship with its target, substantial, organizational and effective components, so changes in the goals (the focus on the developing of competences) require the relevant content and training technologies, the analysis of the results allows to adjust other system components to adapt it to certain requirements, to increase its effectiveness. The article does not exhaust all the aspects of the research problem. The prospective areas are: professional orientation of the pupils of general secondary education institutions on the teaching profession as a stage of continuous pedagogical education; professional competence of a teacher of history and law; the innovative methods and technologies of training; organization of the methodological work in a secondary school as a way of professional development of teachers; external environment of the system and the relevant factors of influence and the like.

\section{ЛITEPATУРА}

1. Bain R. History as Knowledge: Ethical Values and Meaning in Encounters with History / R. Bain. Frankfurt, Germany: Peter Lang, 2015. - P. 121-129.

2. Барбер М. Как добиться стабильно високого качества обучения в школах. Уроки анализа лучших систем школьного образования мира (пер. с анг.) / М. Барбер, М. Муршед // Вопросы образования. -2008. - № 3. - C. 7-60.

3. Burke F. The Five Cs of History: Putting the Elements of Historical Thinking into Practice in Teacher Education / F. Burke, T. Andrews // History Education 101: The Past, Present, and Future of Teacher Preparation, ed. Wilson J. Warren and D. Antonio Cantù. - Charlotte, NC: Information Age Publishing, 2008. - P. 151-166.

4. Галузева Концепція розвитку неперервної педагогічної освіти: Наказ Міністерства освіти і науки України від 15.08.2013 p. - Retrieved from: http://www.kmu.gov.ua/control/publish/article?art_id=246597907

5. Haynes A. Moving Beyond Assessment to Improving Students' Critical Thinking Skills: A Model for Implementing Change / A. Haynes, E. Lisic, M. Goltz, B. Stein, K. Harris // Journal of the Scholarship of Teaching and Learning. - 2016. - № 16 (4). - P. 44-61. - Retrieved from: https://doi.org/10.14434/josotl.v16i4.19407

6. Закон України «Про вищу освіту» від 01.07.2014 р. (за станом на 18.02.2016 р.). - Retrieved from: http://zakon5.rada.gov.ua/laws/show/1556-18

7. Закон України «Про загальну середню освіту» від 13.05.1999 р. (за станом на 07.02.2017 р.). Retrieved from: http://zakon3.rada.gov.ua/laws/show/651-14

8. Закон України «Про освіту» від 05.09.2017 p. - Retrieved from: http://ru.osvita.ua/legislation/law/2231/

9. Kitchen J. Teacher Preparation in Ontario: A History / J. Kitchen, D. Petrarca // Teaching and Learning. 2014. - № 8 (1). - P. 56-71.

10. Концепція «Нова українська школа»: рішення колегії МОН України від 27.10.2016 p. - Retrieved from: http: mon.gov.ua/Новини 2016/12/05/konczepcziya

11. Онуфріснко Н. Європейські цінності у професійній підготовці вчителів історії (кінець XX - початок XXI ст.) / Н. Онуфрієнко // Культура народов Причерноморья. - 2007. - № 104. - С. 134-137. 
12. Пасічник В. Р. Система підготовки вчителя історії у Польщі (80-90 роки ХХ століття): автореф. дис. ... канд. пед. наук: 13.00.04 / В. Р. Пасічник. - К., 2003. - 15 с.

13. Педагогічна Конституція Європи // Вища освіта України. - 2013. - № 3. - С. 111-116.

14. Професійна педагогічна освіта: становлення і розвиток педагогічного знання: монографія / за ред. О. А. Дубасенюк. - Житомир: Вид-во ЖДУ ім. І. Франка, 2014. - 443 с.

15. Quam-Wickham N. Reimagining the Introductory U.S. History Course / N. Quam-Wickham // The History Teacher. - 2009. - № 49(4). - P. 519-548.

16. Shopkow, L. (2017). How Many Sources Do I Need? / L. Shopkow // The History Teacher. - 2017. № 50 (2). - P. 169-200.

\section{REFERENCES}

1. Bain R. History as Knowledge: Ethical Values and Meaning in Encounters with History. - Frankfurt, Germany: Peter Lang, 2015, pp. 121-129.

2. Barber M. Kak dobitsya stabilno visokogo kachestva obucheniya v shkolah. Uroki analiza luchshih sistem shkolnogo obrazovaniya mira (per. s ang.) / M. Barber, M. Murshed [How to achieve a consistently high quality of teaching in schools. The lessons of the analysis of the best school systems in the world (trans. from Engl.)]. Voprosyi obrazovaniya, 2008, № 3, pp. 7-60.

3. Burke F. The Five Cs of History: Putting the Elements of Historical Thinking into Practice in Teacher Education. / F. Burke, T. Andrews. History Education 101: The Past, Present, and Future of Teacher Preparation, ed. Wilson J. Warren and D. Antonio Cantù. - Charlotte, NC: Information Age Publishing, 2008), pp. 151-166.

4. Haluzeva Kontseptsiya rozvytku neperervnoyi pedahohichnoyi osvity: Nakaz Ministerstva osvity i nauky Ukrayiny vid 15.08.2013 r. [The Branch Concept of the development of the continuous pedagogical education: the order of the Ministry of Education and Science of Ukraine of 14.08.2013].

5. Haynes A. Moving Beyond Assessment to Improving Students' Critical Thinking Skills: A Model for Implementing Change. / A. Haynes, E. Lisic, M. Goltz, B. Stein, K. Harris. Journal of the Scholarship of Teaching and Learning, 2008, № 16(4), pp. 44-61. https://doi.org/10.14434/josotl.v16i4.19407

6. Zakon Ukrayiny «Pro vyshchu osvitu»: vid 01.07.2014 r. (za stanom na 18.02.2016 r.). [On higher education: the Law of Ukraine of 01.07.2014 (as 18.02.2016)].

7. Zakon Ukrayiny «Pro zahal'nu serednyu osvitu» vid 13.05.1999 r. (za stanom na 07.02.2017 r.). [About secondary education: the Law of Ukraine of 13.05.1999 (as 07.02.2017)].

8. Zakon Ukrayiny «Pro osvitu» vid 05.09.2017 r. [On education: the Law of Ukraine (draft) of 30.03.2016].

9. Kitchen J. Teacher Preparation in Ontario: A History / J. Kitchen, D. Petrarca. Teaching \& Learning, 2014, № 8(1), pp. 56-71.

10. Kontseptsiya «Nova ukrayins'ka shkola»: Rishennya kolehiyi MON vid 27.10.2016 r. [The concept of the «New Ukrainian School»: the Decision of the Board of the MES of 27.10.2016].

11. Onufriyenko N. Yevropeys'ki tsinnosti u profesiyniy pidhotovtsi vchyteliv istoriyi (kinets' XX - pochatok XXI st.) [The European values in the professional training of history teachers (the end of XX - beginning of XXI centuries] / N. Onufriyenko, Kul'tura narodov Prychernomor'ya, 2007, № 104, pp. 134-137.

12. Pasichnyk V. R. Systema pidhotovky vchytelya istoriyi u Pol'shchi (80-90 roky XX stolittya): avtoref. dys. na zdobuttya nauk. stupenya kand. ped. nauk: spets. 13.00.04 «Teoriya i metodyka profesiynoyi osvity» [The system of training of history teachers in Poland (80-90s of the twentieth century)] / V. R. Pasichnyk, K., 2003, 15 s.

13. Pedahohichna Konstytutsiya Yevropy [Pedagogical Constitution of Europe]. Vyshcha osvita Ukrayiny, 2013, № 3, pp. 111-116.

14. Професійна педагогічна освіта: становлення і розвиток педагогічного знання: монографія [Professional pedagogical education: formation and development of pedagogical knowledge: monograph], ed. O. A. Dubasenyuk (Zhytomyr: Vyd-vo ZhDU im. I. Franka), 2014, 443 s.

15. Quam-Wickham N. Reimagining the Introductory U. S. History Course / N. Quam-Wickham, The History Teacher, 2016, № 49(4), pp. 519-548.

16. 1Shopkow L. How Many Sources Do I Need? / L. Shopkow, The History Teacher, 2017, № 50(2), pp. 169-200.

Стаття надійшла в редакиію 13.02.2018 p. 